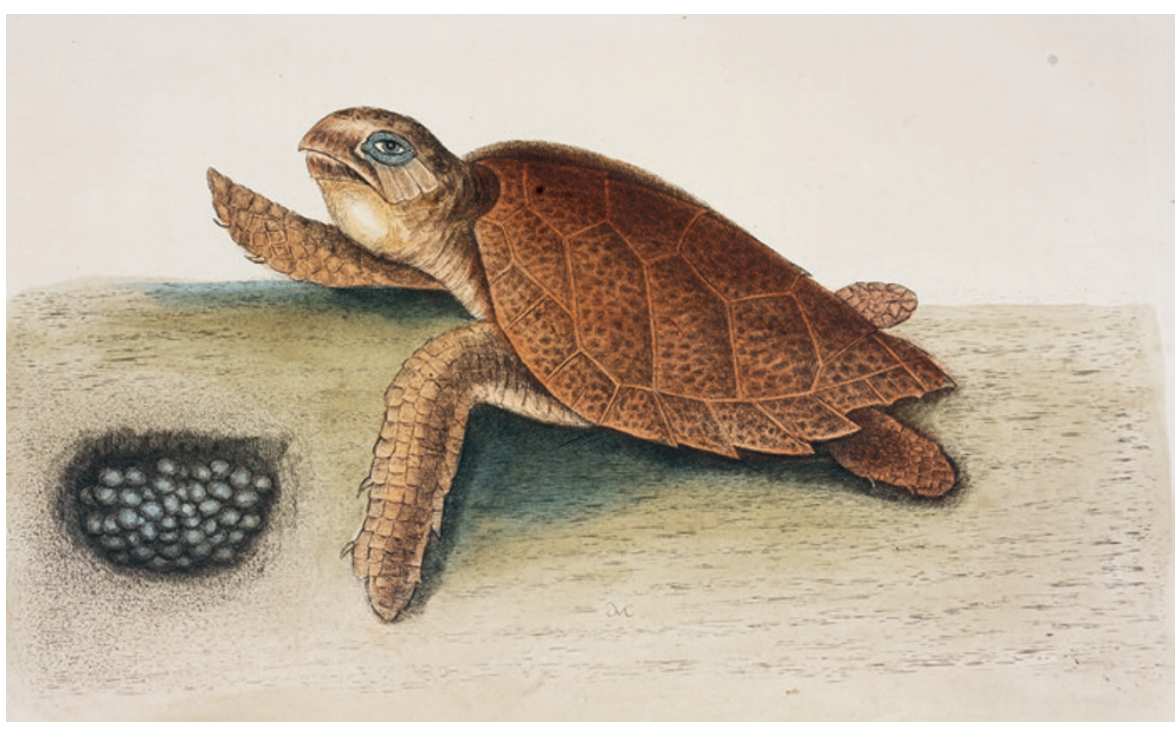

Catesby's rendition of Eretmochelys imbricata, the hawksbill sea turtle. relations between the United States and Britain after the American War of Independence (1775-83). As US artists and naturalists such as Alexander Wilson, William Bartram and John James Audubon became popular, the British pioneer - whose pre-Linnean classifications were by then outmoded - was largely forgotten. There were so few copies of Catesby's volumes in existence by the midnineteenth century that his work was rarely seen, further contributing to his obscurity.

The Curious Mister Catesby will stand for many years as the best critical analysis of his work, and of the groundbreaking natural science that his curiosity inspired.

Linda Lear is a historian of the American environment, an authority on Rachel Carson and author of Beatrix Potter: The Extraordinary Life of a Victorian Genius. e-mail: linda@lindalear.com

\title{
Total recall, welcome oblivion
}

\section{Alison Abbott enjoys a collection of essays on memory and forgetting.}

$\mathrm{H}$ istorian of psychology Douwe Draaisma knows well how to weave science, history and literature into irresistible tales. Forgetting, his latest collection of essays around the theme of memory, is - like his successful Nostalgia Factory (Yale University Press, 2013) - hard to put down.

His vivid tour through the history of memory-repression theories brings home how dangerous and wrong, yet persistent, were the ideas of Sigmund Freud and his intellectual heirs. Freud thought that traumatic memories and shameful thoughts could be driven from the consciousness, but not forgotten. They would simmer in the unconscious, influencing behaviour. He maintained that forcing them out with psychoanalysis, and confronting patients with them, would be curative.

Draaisma relates the case of an 18-year-old whom Freud dubbed Dora, diagnosed in 1900 with 'hysteria'. Dora's family refused to believe that the husband of her father's mistress had made sexual advances to her. Among other absurdities, Freud told Dora that her nervous cough reflected her repressed desire to fellate the man. Dora broke off the therapy, which Freud saw as proof of his theory. He thought that patients will naturally resist reawakening painful thoughts.

What Dora did not buy, plenty of others did. Psychoanalysis boomed, becoming lucrative. Its principles

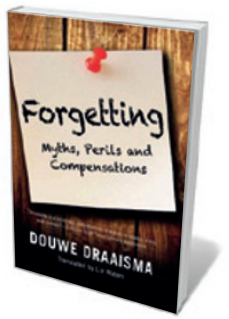

Forgetting: Myths, Perils and Compensations DOUWE DRAAISMA, TRANSLATED BY LIZ WATERS

Yale Univ. Press: 2015 now know from studies of post-traumatic stress disorder that traumatic memories are impossible to repress. They flood into the conscious mind in horrifying flashbacks.

Still, as Draaisma shows, theories of memory repression remain stubbornly attractive. We learn that revered Canadian neurosurgeon Wilder Penfield contributed to their longevity. During surgery for epilepsy, he electrically stimulated points on the surface of conscious patients' brains, and asked the patients what they felt. He was one of the first to map the functions of the sensory and motor cortices. His cartoon of a homunculus with body parts in proportion to the brain space dedicated to them - big lips, for example, and huge hands on spindly arms - is a neuroscience icon.

More controversial was his reading of another experiment. When Penfield stimulated the temporal lobe, his patients reported flashes of dream-like sensations such as the sound of a carnival; he interpreted these as memory traces. He thought that nothing was truly forgotten, and that buried memories could be reactivated. This concept of total recall resonated for a long time in the public imagination. Recent interpretations of his work, however, debunk the idea that he had picked up true memory traces. Fewer than $10 \%$ of people experienced any sensation during temporal-lobe stimulation, and of those that did, the actual words recorded in their notes rarely corresponded to things that could be real memories. As Draaisma drolly notes, Penfield's patients reported nothing worthy of repression anyway. Only "snippets of respectable but humdrum lives ... no incestuous desires, no masturbation fantasies".

In another essay, the patient H. M. (Henry Molaison), who was unable to lay down fresh memories after experimental epilepsy surgery, gets a new biography revealing the misdemeanours of his surgeon. Elsewhere, Draaisma muses on aides-memoires such as photographs, and techniques for forgetting. However, one or two essays show the strains of stretching the formula of memory-related essays to the margin of the theme, where the impact is less important or interesting.

Alison Abbott is Nature's senior European correspondent. 